\title{
Picture Of Age Factors And Sexual Activity With The Incidence Of Benign Prostate Hyperplasia
}

\author{
Hamdana 1, Fatmawati * \\ Departemen Medical Surgical Nursing , Stikes Panrita Husada Bulukumba, Indonesia ${ }^{1}$ \\ Departemen Mental Health Nursing , Stikes Panrita Husada Bulukumba ,Indonesia ${ }^{2}$
}

Corresponding Autor : nengfatma@Gmail.com*

\begin{abstract}
In Indonesia Prostate Hyperplasia Benigna Based on the autopsy rate of microscopic changes at the age of 30-40 years. When microscopic changes develop, anatomic pathologic changes occur in men aged 50 years, the incidence rate is around $50 \%$. 80 years old around $80 \%$ and 90 years old 100\%. Prevalence increases because of an increase in life expectancy. The results of a survey conducted on Benigna Prostate Hyperplasia patients at H. Andi Sulthan Daeng Radja Hospital in Bulukumba District, patients with Benigna Prostate Hyperplasia have an average age of $>50$ years as many as 30 people. This study aims to determine the description of age and sexual activity with the incidence of hyperplasia prostate benign disease in H. Andi Sulthan Daeng Radja District Hospital. This study uses a descriptive approach with a population of 30 and is sampled. Sampling using the Total Sampling method. The results of research on the incidence of prostate hyperplasia benign disease mostly occur with age and partial sexual activity who experience benign prostatic hyperplasia more normal sexual activity 1-2 times/weeks and only a few are abnormal sex frequency. The conclusion of the study is the age category of the initial elderly as many as 7 people (23.3\%), the final elderly as many as 8 people (26.7\%). While the age of seniors as many as 15 people $(50 \%)$ the category of normal sex frequency $<3$ times/week as many as 16 respondents (53.3\%) and as many as 14 respondents (46.7\%) who do sexual frequency $>3$ times a week. The suggestion from this research is that it should pay attention to various aspects that can influence the occurrence of hyperplasia prostate benign in patients so that its incidence can be prevented and can provide good service, as well as the right action for sufferers of benign prostatic hyperplasia.
\end{abstract}

Keywords: Benign Prostate Hyperplasia, Age, Sexual Activity

\section{INTRODUCTION}

Benign Prostate Hyperplasia is a hyperplasia condition from the periurethral region which then meets prostate tissue that is native to the peripheral (Jong, 2004 in Asnita 2014). The prostate gland is useful for protecting spermatozoa against pressure from the dilethra and vagina, as well as adding seminal fluid. In some patients over the age of 50 years, discussing the prostate to increase magnification, because it affects changes in testosterone and estrogen, in some cases the prostate can extend upward through the bladder and open urine flow using the urethral orifice. This condition is known as benign prostatic hyperplasia (BHP), enlargement, or prostatic hypertrophy. BPH is the most common pathological problem in elderly men and the second most popular cause 


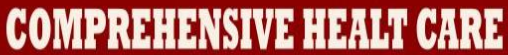

for medical protection in men over the age of 60 years (Brunner \& Suddarth, 2001 in Asnita 2014).

Benign Prostate Hyperplasia will arise with age, because Benigno Prostate Hyperplasia will argue with the aging process. Benign prostate hyperplasia compared to other disorders, such as prostate cancer, is indeed common (Palindrungi, 2008 in Rasyidin, 2013). The most common form of prostate malignancy is prostate adenocarcinoma, other rare forms are: sarcoma (0.1-0.2\%), transitional cell carcinoma (1-4\%), lymphoma and leukemia. Therefore when we discuss prostate cancer connotes as prostate adenocarcinoma. Prostate cancer is currently the most common type of noncutaneous malignancy in western countries or the 4th most common malignancy in men worldwide after skin, lung and colon cancer (Epstein, Mottet, Boyle, Klein, Moffet, 2007 2008 in 2007-2008) KPKN, 2015).

Worldwide, it is estimated that approximately $50 \%$ of men who are accepted over 60 years old are questioned by Benigno Prostate Hypertrophy, between 15\% and 30\% of these men have lower complaints about urinary tract symptoms (LUT), at the age of 80 years the incidence increased to 90\% (Thorpe, Neal, 2003 in Rasyidin, 2013). Meanwhile according to Letran and Brawer (1999) cited by Parsudi and Martono (2001 in Rashidin, 2013) in the United States only 1 in 4 continued in men aged 80 years who eliminated lower urinary contracts (LUTS) as a result of enlarged prostate enlargement, Embossed microscopic nodules in the prostate have been seen at the age of 25-30 years, and is $60 \%$ of men borrowed 60 years, while at the age of 85 years there are $90 \%$ of sufferers. Some of these patients can develop total urinary retention / acute prostatism damage or improve renal insufficiency due to chronic urinary retention. The World Health Organization (WHO) reports that in 2012, two-thirds of the elderly rescued by the world, who earned 600 million, will live and live in developing countries, increasing as much as this will happen in Asia.

Until now, the population in 11 WHO member countries in the Southeast Asia region that received 60 years ago 142 million people and is expected to continue to increase three times in 2050. But with this life expectancy, WHO estimates the number of Benigno Prostate Hyperplasia in the world around 30 million sufferers and will increase also in the coming years (WHO, 2009 in Rasyidin, 2013). In Indonesia Prostate Hyperplasia has a significant morbidity in the elderly population, with growing age there will be a change in the balance of testosterone and estrogen. Based on the autopsy rate 


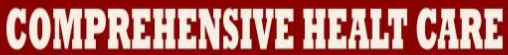

of microscopic changes at the age of 30-40 years. When microscopic changes develop, anatomic pathologic changes occur in men aged 50 years, the incidence rate is around $50 \%$. 80 years old around $80 \%$ and 90 years old 100\%. The prevalence increases because of an increase in life expectancy (Mansjoer, 2004 in Asnita, 2014).

In H. Andi Sulthan Daeng Radja Hospital, Bulukumba Regency, the Surgery / Urology sub-section, every year there are under 100 patients with hyperplasia. In the last 3 years there has been an increase in the number of sufferers of benign prostate hyperplasia. In 2013 there were 71 patients, in 2014 there were 90 patients, in 2015 there were 89 patients, and the number of Prostate Hypertropic patients who entered 2016 to February was 27 patients (Medical Record of H. Andi Sulthan Daeng Radja Hospital, Bulukumba Regency, 2016 ). The results of a survey conducted on Benigno Prostate Hyperplasia patients at H. Andi Sulthan Daeng Radja Hospital in Bulukumba District, patients with Benigno Prostate Hyperplasia have an average age of $>50$ years as many as 27 people (30.3\%). There are some Benigna Prostate Hyperplasia patients undergoing surgery because the swelling is too large, some patients who quickly get the disease undergoing outpatient treatment. If this happens, the main treatment is usually done by medical. If the medication is unsuccessful, surgery will be performed (Toha, 2007 in Asnita, 2014). The structure of Indonesian society changed from a young population / population in 1971 to an older population in 2020. This shift demands a change in health care strategies, in other words, more attention and priority to diseases in the age of adulthood and old age, one of them is Prostate Hypertrophy without ignoring disease in toddlers and children. Prostate enlargement is considered as part of the process of increasing age, as well as white hair. Therefore, with the increase in life expectancy, the prevalence of prostate hypertrophy also increases (Rasyidin, 2013).

Factors affecting Prostate Hyperplasia are the background of the patient's condition such as age, family history, high animal fat diet, lack of fiber diet, smoking, and sexual activity while unrelated factors are obesity, increased blood cholesterol levels, exercise, drinks alcoholic, and Diabetes Mellitus (Amalia, 2010). Meanwhile, according to the latest research by Rasyidin (2013), factors that influence the occurrence of hyperplasia of prostate benign disease are age, sexual activity and food. Therefore, researchers are interested in further analyzing the factors associated with the incidence of hyperplasia of prostate benign disease in H. Andi Sulthan Daeng Radja Hospital in Bulukumba Regency 


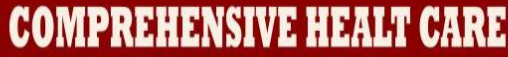

\section{MATERIAL AND METHODS}

This research uses descriptive design which aims to get an accurate picture of a number of characteristics of the problem under study. Descriptive research is useful for getting new meaning, describing the category of a problem, explaining the frequency of an event from a phenomenon (Suyanto, 2011). The population is the whole object of research or that has certain characteristics that are determined by researchers to be studied and drawn conclusions (Suyanto, 2011). The population in this study were all BPH patients treated at H. Andi Sulthan Daeng Radja Bulukumba Hospital.

The population in this study was 89 people. The sample is part of the population that represents a population (Saryono, 2011). The sampling technique used is the sampling technique used in this study is the total sampling technique that is taking the whole sample (Dharma, 2011). the number of samples is 30 people. Researchers collected data using an instrument check list that contained respondents' demographic data to find out age, education, and occupation (Machfoedz, 2009). The cousener sheet used is similarly designed as possible to collect respondent data in private and confidentially. Analysis of the data used is Univariate Analysis which is an analysis carried out for one variable or per variable. Done to get a general picture by describing each variable used in research that is looking at the frequency distribution.

\section{RESULTS}

Table 1. Distribution of Respondent Frequencies Based on Education and Employment

\begin{tabular}{lcc}
\hline Characteristics & $\mathbf{n}$ & Percentage (\%) \\
\hline Education & 17 & 56.7 \\
Low & 10 & 33.3 \\
Intermediate & 3 & 10.0 \\
High & & \\
Profession & 2 & 6.7 \\
Labor & 23 & 76.7 \\
Farmers & 3 & 10.0 \\
entrepreneur & 2 & 6.7 \\
Does not work & $\mathbf{3 0}$ & $\mathbf{1 0 0 , 0}$ \\
\hline Amount & & \\
\hline
\end{tabular}

Based on table 1 above from 30 respondents showed that the frequency of respondents based on education there were 17 respondents (56.7\%) who were in lower education, 10 respondents (33.3\%) who were in secondary education and 3 respondents (10.0\%) who were in higher education . 23 respondents (76.7\%) had jobs as farmers, while 2 respondents (6.7\%) did not work. 
Table 2. Distribution of Respondents by Age Factor with Prostate Hyperplasia Benign Disease

\begin{tabular}{lcc}
\hline Age & n & Precentage (\%) \\
\hline Early elderly & 7 & 23.3 \\
Late elderly & 8 & 26.7 \\
Old age & 15 & 50.0 \\
\hline Amount & $\mathbf{3 0}$ & $\mathbf{1 0 0}$
\end{tabular}

Based on table 2 it is known from 30 respondents, showing that the frequency of respondents based on age is the same, namely the age of the initial elderly as many as 7 people (23.3\%), the final elderly as many as 8 people (26.7\%). While the age of 15 people (50\%) who have prostate hyperplasia benign disease with a positive diagnosis in H. A. Sulthan Hospital Dg Radja Bulukumba.

Table 3. Distribution Based on Factors of Sexual Activity with the Occurrence of Prostate Hyperplasia

\begin{tabular}{lcc}
\hline Sexual Activity & $\mathbf{n}$ & Percentage (\%) \\
\hline Normal sex frequency & 16 & 53.3 \\
The frequency of abnormal sex & 14 & 46.7 \\
\hline Amount & $\mathbf{3 0}$ & $\mathbf{1 0 0}$ \\
\hline
\end{tabular}

Based on table 3 above, it is known from 30 respondents, showing that the frequency of respondents based on normal sex frequency $<3$ times / week was 16 respondents (53.3\%) and as many as 14 respondents (46.7\%) who had sexual frequency $>3$ times a week who had Benign Disease Prostate Hyperplasia with a positive diagnosis at HA Sulthan Hospital Dg Radja Bulukumba.

\section{DISCUSSION}

Based on table 5.2 above it is known from 30 respondents, showing that the frequency of respondents based on age is the age of the initial elderly as many as 7 people (23.3\%), the final elderly is 8 people (26.7\%). While the age of 15 people (50\%) who have prostate hyperplasia benign disease with a positive diagnosis in $\mathrm{H}$. A. Sulthan Hospital Dg Radja Bulukumba. This study is in line with that carried out by Zahi Rasyidin (2013), with the title "Factors Related to Prostate Occurrence in the Inpatient Room of the Ibnu Sina Hospital in Makassar" This study uses descriptive analytic research with cross sectional design. The analysis uses the Chi-Square test. Subjects in the study conducted by Zahi Rasyidin were sufferers of urinary tract disorders, especially in prostate hypertrophy patients at the hospital. Ibnu Sina Makassar.

Based on the data analysis, it was found that the results of research conducted in the Inpatient Room of the Ibnu Sina Hospital in Makassar showed that the elderly respondents mostly experienced Prostate Hypertrophy (88.9\%) while only half the respondents were adults who experienced Prostate Hypertrophy (50.0\%). Based on the 


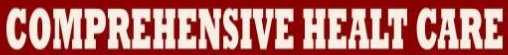

results of the Fisher Exact Test statistical test $p$ value $=0.034$, this means the value of $p$ $<\alpha(0.05)$, which means there is a relationship between age and prostate hypertrophy in the Inpatient Room of Ibnu Sina Hospital Makassar. This research is in line with research conducted by Hartati (2007). The results of his study showed that there was a relationship between age and the incidence of benign prostate hyperplasia (BPH) in Seruni Room (B2) Dr. M. Yunus Bengkulu ( $p=0.030)$.

This study is also in line with Rizki's research (2010) where the results of the study show that the risk factors that are proven to influence the occurrence of prostatic hypertrophy Benigna are Age (OR adjusted = 6.24; 95\%; Confidence Interval: 1.7122.99; $\mathrm{p}=0.006)$. The prostate continues to grow at a young age, getting bigger with a man's age. This is in line with the opinion of Purnomo (2010) that as we age there will be a change in hormonal balance, which is between the hormone testosterone and the hormone estrogen. Because testosterone production decreases and conversion of testosterone into estrogen in peripheral adipose tissue with the help of the enzyme aromaterase, where the nature of this estrogen will stimulate the sensitivity of prostate cell receptors until the cells get bigger (hyperplasia of the stroma) which will eventually suppress the urethra and inhibit the flow urine With increasing age, there will be a decrease in testicular function (spermatogenesis) which will cause a progressive decline in androgen secretion and often does not cause symptoms or complaints from the concerned. A new person feels that there is an enlarged prostate if there are complaints of urination or urination disorders.

Based on the analysis of research says that, hyperplastic prostate benign disease is closely related to increased levels of dihydrotestosteren (DHT) and the aging process. The prostate develops when it is still young, getting bigger with age as autopsy rates based on microscopic changes in the prostate can be found at the age of 30-40 years. If these microscopic changes continue to develop, anatomic pathologic changes will occur. In men aged 50 years the rate of about $50 \%$ and at the age of 80 years around $80 \%$. About $50 \%$ of the figures mentioned above will cause symptoms and clinical signs, the process of prostate enlargement occurs slowly. This is due to the enlargement of the prostate varies in each man. Prostate Benign Hyperplasia is closely related to age because with increasing age, there will be a change in the balance of testosterone and estrogen due to decreased testosterone production and the conversion of testosterone to estrogen in peripheral adipose tissue. Benign prostatic hyperplasia occurs at age $\geq 50$ 
years associated with general weakness including weakness in the bladder and can feel complaints of urination or urinary disorders so that benign prostatic hyperplasia can occur easily due to the influence of old age.

This is in line with the opinion of Yatim (2004) in Sujiyati's research (2010) that the more elderly, the more risky the occurrence of BPH. In men aged 50 years, about 33\% are estimated to have a small prostate tumor, and at the age of 80 years around $70 \%$. In old age increased testosterone and androgen hormones can increase the risk of BPH. Based on table 5.3 above, it is known from 30 respondents, showing that the frequency of respondents based on normal sex frequency $<3$ times / week was 16 respondents (53.3\%) and as many as 14 respondents (46.7\%) who had sexual frequencies $>3$ times a week who had Benign Disease Prostate Hyperplasia with a positive diagnosis at HA Sulthan Hospital Dg Radja Bulukumba.

This research is in line with what was done by Zahi Rasyidin (2013). The results showed that in the Inpatient Room of the Ibnu Sina Hospital Makassar showed that respondents whose sexual activity was at risk mostly experienced Prostate Hypertrophy (86.4\%) while respondents whose sexual activity was not at risk all did not experience Prostate Hypertopy (100.0\%). Fisher Exact Test statistical test results obtained p value $=0.003$, this means the value of $\mathrm{p}<\alpha(0.05)$ which means there is a relationship between sexual activity with prostate hypertrophy in the Inpatient Room of Ibnu Sina Hospital

Makassar. Sexual activity is any form of behavior that appears related to sexual urges. Sexual intercourse means sexual relations as a form of sexual drive distribution (National Family Planning Coordinating Board, 2010). Sexual activity was first reported by Gover as a possible causative factor for the development of Prostate Hypertrophy using marital status as a representative. Ekman states that an increase in the fibromuscular component of Prostate Hypertrophy may be an activity (Rasyidin, 2013).

This research is in line with the opinion of Hellstrom (2007) in Rizki (2010) the prostate gland is the organ responsible for the formation of male hormones. Benign prostate hyperplasia is associated with excessive sexual activity and hygiene reasons. During sexual activity, the prostate gland experiences an increase in blood pressure before ejaculation occurs. If the blood supply to the prostate is always high, prostate blockage will occur which results in permanent swelling of the gland. Unclean sex will result in prostate infection resulting in prostate hyperplasia. High sexual activity is also 
associated with increased levels of the hormone testosterone. Based on the analysis of research says that, the incidence of benign prostate hyperplasia can be influenced by sexual activity that is too frequent and never engage in sexual activity due to the distance of each partner. During sexual activity, the prostate gland experiences an increase in blood pressure before ejaculation occurs. If the blood supply to the prostate is always high, prostate blockage will occur which results in the glands being swollen permanently, so as to avoid the occurrence of prostatic hyperplasia, the sexual activity must be regulated as well as possible. Benign prostatic hyperplasia has not yet been detected when it is young but was detected when it was getting older because of a decrease in the body's ability to balance sexual activity and is also associated with an increase in the hormone DHT (Dihidrotestosterone).

In line with the opinion of Wimpie (2001) in the study of Sujiyati (2010) normal sexual needs in one week for married couples that is, depending on the willingness and ability of each partner. This is also in line with the opinion of Miller (1990) Sujiyati (2010) that encouragement of libido can determine the intensity of sex. Agree also with Henny (2008) Sujiyati (2010) that there are no rules that require a person to have intercourse a day or a week how many times. It all depends on the communication from each partner.

\section{CONCLUSIONS}

From 30 respondents who diagnosed benign prostatic hyperplasia based on sexual activity were normal sexual frequency 1 - 3 times / week as many as 14 respondents (46.7\%) and as many as 16 respondents (53.3\%) who had abnormal sexual frequency> 3 times a week or who experienced Benign prostate hyperplasia disease with a positive diagnosis in HA Sulthan General Hospital, Dg Radja Bulukumba. For hospitals, it should pay attention to various aspects that can be influence the occurrence of BPH in patients so that their incidence can be prevented and can provide good services, as well as appropriate actions for patients with BPH.

\section{REFERENCES}

Arwin, 2014. Hubungan Pengetahuan Pasien Tentang Diet Makanan Dengan Frekuensi Kekambuhan Pasien Rheumatoid Arthritis (RA) di Puskesmas Balibo Kecamatan Kindang Kabupaten Bulukumba Tahun 2014. Skripsi. 
Asdar , 2015. Hubungan Karakteristik Ibu Hamil Trimester III Dengan Tingkat Kecemasan Menghadapi Proses Persalinan Di Wilayah Kerja Puskesmas Gattareng Tahun 2015. Skripsi.

Asnita, 2014. Gambaran Karakteristik Penderita Penyakit Hipertropi Prostat Di RSUD. H. Andi Sulthan Daeng Radja Kabupaten Bulukumba Tahun 2014. Karya Tulis Ilmiah.

Dharma, 2011. Metodologi Penelitian Keperawatan (Pedoman Melaksanakan dan Menerapkan Hasil Penelitian). Jakarta: CV. Trans Info Media.

Hendrik, 2011 Tingkat Pengetahuan tentang proses dan pemeriksaan penelitian. Sekolah Tinggi Ilmu Keshatan Surakarta.

Nursalam, 2013. Konsep dan Penerapan Metodologi Penelitian IImu Keperawatan. Surabaya : Salemba Medika

Nurarif, 2015. Aplikasi Asuhan Kepereawatan Berdassarkan Diagnosa Medis dan Nanda Nic-Noc. Jogjakarta: Mediacton Jogja.

KPKN, 2015. Panduan Nasional Penanganan Kanker Prostat. Ikatan Ahli Urologi Indonesia. Jakarta: Komite Penanggulangan Kanker Nasional (KPKN).

Kumalasari, 2011. Perbedaan Angka Kejadian Benign Prostatic Hyperplasia Pada Usia Antara 50-59 Tahun Dengan Usia Diatas 60 Tahun Pada Pemeriksaan Ultrasonografi Di RS.PKU (Pembina Kesejahteraan Umat) Muhammadiyah Surakarta. Jurnal.

La Ode, 2012. Konsep Dasar Keperawatan, Cet.1. Jogyakarta: Nuha Medika.

Mutaqqin, 2012. Asuhan Keperawatan Gangguan Sistem Perkemihan. Jakarta· Salemba Medika.

Machfoedz, 2010. Tehnik Membuat Alat Ukur Penelitian Bidang Kesehatan, Keperawatan, dan Kebidanan. Jakarta: Tramajaya.

Nursalam. 2010. Konsep Dasar Penerapan Metodologi Penelitian Ilmu Keperawatan: Pedoman Skripsi, Tesis, Dan Instrument Penelitian Keperawatan. Salemba Medika: Jakarta.

Rekam Medik, 2016. Jumlah Penderita Penyakit Prostat. RSUD H.A.Sulthan Dgn Radja Bulukumba.

Riyanto, 2011. Pengolahan Dan Analisis Data Kesehatan. Yogyakarta: Nuha Medika.

Saryono. (2011). Metodologi Penelitian Kesehatan Penuntun Praktis Bagi Pemula.

Jogjakarta: Mitra Cendikia. 
Sinatra, 2015. WHO Mengeluarkan Kriteria Baru Kelompok Usia . http://erabaru.net/2015/08/19/who-mengeluarkan-kriteria-barukelompok-usia/

Suhartini, 2013. Pengaruh Teknik Relaksasi Terhadap Intensitas Nyeri Pada Pasien Post Operasi Fraktur Di Ruang Irnina A BLU RSUP PROF Dr. R.D KANDOU MANADO. Jurnal.

Suyanto, 2011. Metodologi dan Aplikasi Penelitian Keperawatan. Nuha Medika. Yogyakarta.

Tuslihah, 2011. Hubungan Umur, Paritas dengan Pengetahuan Ibu Hamil Tentang Antenatal Care di Wilayah Kerja Puskesmas Kagok Semarang. Jurnal kebidanan Semarang.

Yanti, 2015. Kategori Umur Menurut Depkes. http://yhantiarita.wordpress.com/2015/06/03/kategori-umur-menurutdepkes/

Zahi, 2013. Faktor-Faktor Yang Berhubungan Dengan Kejadianhipertropi Prostat Di Ruang Rawat Inaprumah Sakit Ibnu Sina Makassar. Jurnal. 